\title{
Tracing inputs of terrestrial high molecular weight dissolved organic matter within the Baltic Sea ecosystem
}

\author{
B. Deutsch ${ }^{1,2}$, V. Alling ${ }^{3}$, C. Humborg ${ }^{1,2}$, F. Korth ${ }^{4}$, and C. M. Mörth ${ }^{2,5}$ \\ ${ }^{1}$ Department of Applied Environmental Science, Stockholm University, 11418 Stockholm, Sweden \\ ${ }^{2}$ Baltic Nest Institute, Stockholm Resilience Centre, Stockholm University, 10691 Stockholm, Sweden \\ ${ }^{3}$ Norwegian Geotechnical Institute, Postboks 3930 Ullevål Station, 0806 Oslo, Norway \\ ${ }^{4}$ Leibniz Institute for Baltic Sea Research, Seestr. 15, 18119 Rostock, Germany \\ ${ }^{5}$ Department of Geological Sciences, Stockholm University, 11418 Stockholm, Sweden
}

Correspondence to: B. Deutsch (barbara.deutsch@itm.su.se)

Received: 11 December 2011 - Published in Biogeosciences Discuss.: 16 April 2012

Revised: 8 October 2012 - Accepted: 16 October 2012 - Published: 13 November 2012

\begin{abstract}
To test the hypothesis whether high molecular weight dissolved organic matter (HMW-DOM) in a high latitude marginal sea is dominated by terrestrial derived matter, 10 stations were sampled along the salinity gradient of the central and northern Baltic Sea and were analyzed for concentrations of dissolved organic carbon as well as $\delta^{13} \mathrm{C}$ values of HMW-DOM. Different end-member-mixing models were applied to quantify the influence of terrestrial DOM and to test for conservative versus non-conservative behavior of the terrestrial DOM in the different Baltic Sea basins. The share of terrestrial DOM to the total HMW-DOM was calculated for each station, ranging from 43 to $83 \%$. This shows the high influence of terrestrial DOM inputs for the Baltic Sea ecosystem. The data also suggest that terrestrial DOM reaching the open Baltic Sea is not subject to substantial removal anymore. However compared to riverine DOM concentrations, our results indicate that substantial amounts of HMW-DOM ( $>50 \%$ ) seem to be removed near the coastline during estuarine mixing. A budget approach yielded residence times for terrestrial DOM of 2.8, 3.0, and 4.5 yr for the Bothnian Bay, the Bothnian Sea and the Baltic Proper.
\end{abstract}

\section{Introduction}

Soil organic matter, which forms the major part of terrestrial DOM, is one of the world's largest reservoirs of organic carbon. Globally around $1500 \mathrm{Gt}$ organic carbon are stored in the soils at depths between 0-200 cm (Zimov et al., 2006), and only partly degradation and release of this organic carbon will increase the atmospheric $\mathrm{CO}_{2}$ levels by several ppm (Friedlingstein et al., 2006). DOM plays an important role in the aquatic cycles of $\mathrm{C}, \mathrm{N}$, and $\mathrm{P}$, where it serves as an energy source and as a nutrient, and in the oceans it contributes to eutrophication and hypoxia (Wiegner and Seitzinger, 2004; Stepanauskas et al., 1999; Seitzinger and Sanders, 1997). It consists of a complex mixture of organic compounds, such as lipids, amino acids, sugars, and humic or fulvic acids (Benner, 2002), and every year around $0.25 \mathrm{GtC}\left(0.25 \times 10^{15} \mathrm{~g}\right)$ are transported as DOM via the rivers to the coastal oceans (Cauwet et al., 2002).

In the last decade major research focus has been put on the carbon release from thawing permafrost soils in high latitude systems induced by climate change (Zimov et al., 2009; Tarnocai et al., 2009; Schuur et al., 2008). It is assumed that large amounts of this released organic carbon are transported via the rivers to the coastal oceans, and one important question is how much of this DOC is either retained and degraded in the coastal systems or exported to the open ocean.

Typical DOC concentrations in rivers range between 80 in semi-arid and $660 \mu \mathrm{moll}^{-1}$ in wet tropic regions (Meybeck, 1988). For the period from 1996 to 2000, the average discharge-weighted DOC concentration for all rivers draining into the Bothnian Bay and the Bothnian Sea is 623 and $498 \mu \mathrm{moll}^{-1}$ (data from monthly monitoring in Swedish and Finnish rivers, source: Baltic Nest Institute). In the open Baltic Sea, the concentrations of DOM are much lower (Nausch et al., 2010) indicating either a strong 
removal or dilution. DOM removal can be biotic (e.g. uptake by bacteria, algae, plankton) or abiotic (UV photooxidation, sorption) (Amon and Benner, 1994, 1996; Rivkin and Putt, 1987; Moran and Zepp, 1997, Druffel et al., 1996). Bacteria are the main consumers of DOM, but also some algae as well as phyto- and zooplankton are able to use DOM, and the amount of DOM removal depends strongly on the bioavailability of the DOM. For nine rivers in the USA, DON (dissolved organic nitrogen) and DOC bioavailability ranged between $0-40 \%$ and $1-16 \%$, respectively (Wiegner et al., 2006). For rivers draining into the Baltic Sea, the potential DON bioavailability covers a wide range from 8 $72 \%$ (Stepanauskas et al., 2002), with rivers draining into the northeastern parts of the Baltic showing lower bioavailability $(8-14 \%)$ compared to rivers draining into the remaining area $(29-72 \%)$. The authors explain the lower DON bioavailability in the northeastern rivers with a high proportion of DON originating from peat bogs in that area. This agrees with results published by Williams et al. (2010) that DOM in agriculturally dominated streams shows a higher bioavailability than DOM in wetland streams. In a recent study Korth et al. (2011) found a shift from phytoplankton-dominated DON uptake in the North Sea and central Baltic Sea towards a bacteria-dominated DON uptake in the Bothnian Bay and a weak positive relationship between DON concentrations and uptake.

DOM photo-oxidation occurs during the absorption of sunlight by DOM, and four major types of photoproducts can be produced: (1) low-molecular weight organic compounds, (2) carbon gases, (3) unidentified bleached organic matter, and (4) N- and P-rich compounds, like ammonium and phosphate (Moran and Zepp, 1997). Besides being a removal process, the DOM photo-oxidation also influences the bioavailability of DOM. Even a moderate dose of solar radiation can decrease the DOC bioavailability by $40 \%$ (Stepanauskas et al., 2005).

There is only little knowledge about the importance of DOM sorption by suspended particulate matter for DOM removal, but it is recognized as a possible pathway (Druffel et al., 1996). Studies have shown that, especially during summer when nutrients are depleted, DOM can be an important nutrient fuelling primary production (Berg et al., 2003; Korth et al., 2011; Stepanauskas et al., 1999), and especially for sensible ecosystems like the Baltic Sea terrestrial DOM inputs are assumed to strongly influence the biogeochemistry.

A key issue to understanding the transformations of terrestrial organic carbon in the ocean is to disentangle the latter from marine-produced organic matter (Alling et al., 2008). A useful tool to distinguish between terrestrial (allochthonous) and marine (autochthonous) DOM in coastal oceans is the analysis of stable isotope ratios of $\mathrm{C}$ in HMW-DOM, which represents the DOM fraction between $1 \mathrm{kD}$ and 0.3 or $0.7 \mu \mathrm{m}$ (Benner et al., 1997; Guo et al., 2003, 2009; Sigleo and Macko, 2002). Organic matter from terrestrial sources (C3 plants) is relatively depleted in ${ }^{13} \mathrm{C}\left(\delta^{13} \mathrm{C}:-30\right.$ to $-25 \%$ o compared to organic matter released from marine phytoplankton $\left(\delta^{13} \mathrm{C}\right.$ : -20.9 to $-22.7 \%$ ) (Benner et al., 1997; Guo et al., 2003). It is known that the $\delta^{13} \mathrm{C}$ values of marine DOC relatively well match the $\delta^{13} \mathrm{C}$ values from marine phytoplankton (Benner et al., 1997) which suggests no or only minor isotope fractionation during phytoplankton DOC release. For three different Baltic Sea basins, Rolff and Elmgren (2000) reported average $\delta^{13} \mathrm{C}$ values of $-20.7 \%$ (Baltic Proper), $-23.3 \%$ (Bothnian Sea), and $-25.2 \%$ (Bothnian Bay) in phytoplankton (size fraction 5-100 $\mu \mathrm{m}$ ) in the Baltic Sea. These differences in $\delta^{13} \mathrm{C}$ between the different basins are mainly a result of differences in the $\delta^{13} \mathrm{C}$ values of the dissolved inorganic carbon (DIC) utilized by the phytoplankton and are also influenced by temperature. Terrestrial DIC is showing lower $\delta^{13} \mathrm{C}$ values compared to marine DIC (Peterson and Fry, 1987), and the increasing terrestrial influence is reflected in the decreasing $\delta^{13} \mathrm{C}$ values of the phytoplankton towards the northern parts of the Baltic Sea.

For tracing terrestrial DOM along the Mississippi River plume into the Gulf of Mexico, Guo et al. (2009) used $\delta^{13} \mathrm{C}$ values in HMW-DOM ( $1 \mathrm{kD}-0.2 \mu \mathrm{m})$. They found a seasonal difference as well as an expected gradient with lower $\delta^{13} \mathrm{C}$ values in the Mississippi River (-26.3 and $-25.2 \%$ in $\mathrm{Au}-$ gust and March respectively) and higher values in the high saline waters in the Gulf of Mexico with $-23.1 \%$ in August and $-21.9 \%$ in March.

In the northern parts of the Baltic Sea, Alling et al. (2008) tested in a novel approach the use of $\delta^{34} \mathrm{~S}$-DOS (dissolved organic sulfur) to distinguish between terrestrial and marine DOM. Using this tracer gives the advantage that influences of estuarine-produced DOM can be excluded, due to the large concentration difference between the sulfur compounds in the marine and in the terrestrial environment. Due to a much higher concentration of sulfur in the marine environment, estuarine-produced DOM has a typical marine $\delta^{34} \mathrm{~S}$ value. A second advantage is a much larger range in the $\delta$ values between marine and terrestrial DOM for $\delta^{34} S$ than for $\delta^{13} \mathrm{C}$ (Alling et al., 2008). Unfortunately, the determination of $\delta^{34} \mathrm{~S}$-DOS is very lab-intensive due to an additional ultrafiltration step to remove inorganic $\mathrm{S}$ and furthermore, it requires a much higher sampling volume because of low DOS concentrations. In their study the authors estimated the share of terrestrial DOC in the water column for the Bothnian Bay the Bothnian Sea, and the Baltic Proper of 67, 75, and 87\%, respectively. Furthermore they calculated the residence time for terrestrial DOC, which was much shorter than the hydraulic turnover time and indicated a degradation of DOC within the basins.

Aim of our study was the quantification of terrestrial HMW-DOM along the salinity gradient of the central and northern Baltic Sea, which included also the main basin of the Baltic Sea the Baltic Proper. To distinguish between the autochthonous and allochthonous DOM, we analyzed the stable isotopes of $\mathrm{C}$ in HMW-DOM along the salinity gradient of the central Baltic Sea. The calculation of a theoretical 
mixing curve of the $\delta^{13} \mathrm{C}$-DOM values together with the application of an end-member mixing model allowed us to investigate in detail the distribution and behavior (conservative vs. non-conservative) of terrestrial HMW-DOM in the central and northern Baltic Sea basins. Since Alling et al. (2008) did their study during the winter months, the results from our study - where samples were taken from early spring to late summer - furthermore complete the picture of seasonal HMW-DOM distribution and behavior in the Baltic Sea.

\section{Material and methods}

\subsection{Study area}

The Baltic Sea provides, as a high-latitude semi-enclosed inland sea, an ideal study area for investigating the fate of terrestrially derived dissolved organic matter, since the soils in the northern part of the catchment contain a similar amount of organic carbon compared to the soils in Alaska, Siberia and Russia (IPCC, 2001). The rivers draining into the Bothnian Bay, which forms the northernmost basin of the Baltic Sea, show similar DOC concentrations to the rivers draining into the Arctic Ocean and show - due to comparable climate conditions - a similar runoff scheme with a pronounced snow melt-induced spring flood event. Towards the south the Baltic Sea changes from a sub-arctic to a boreal system. It is composed of several deep basins separated by sills and has a very shallow connection to the North Sea. Due to the high freshwater input, a salinity gradient from nearly full marine (salinity 35) to fresh water conditions (salinity 0) exists, which gives the whole Baltic Sea area an estuarine character. The water residence times range from $0.2 \mathrm{yr}$ in the shallow Danish straits and Kattegat to $5.1 \mathrm{yr}$ in the Bothnian Bay (Bothnian Sea 3.2, Baltic Proper 4.4 yr; Savchuk, 2005). The Darss and Drodgen sills separate the shallow western parts from the deeper central and northern parts of the Baltic Sea (Fig. 1). Due to the special topographic and hydrographic conditions in combination with a high population density and a high proportion of the catchment used for agricultural land use especially in the southern parts of the catchment, the Baltic Sea is very sensitive to influences from the terrestrial landscape and is suffering from eutrophication and bottom water anoxia (Voss et al., 2011).

\subsection{Sampling and analyses}

Samples were taken during two cruises to the Baltic Sea. The first set of samples was taken during a cruise with $\mathrm{r} / \mathrm{v}$ Professor Albrecht Penck on 14 March 2009, where 3 samples were taken along the salinity gradient of the outflow of the Oder lagoon in the Oder (Pomeranian) Bight. The second sampling took place from 25 August to 7 September 2009 during a Baltic Sea transect cruise from Bremerhaven (Germany) through the German Bight, Skagerrak, Kattegat to the mouth of the Kalix River (northern Sweden, Fig. 1) with r/v
Maria S Merian. In total 13 stations were sampled. During the cruises with r/v M. S. Merian and r/v P. A. Penck, surface water samples (1-5 m depth) for DOM ultra-filtration were taken from a sampling rosette with Niskins, attached to a seabird CTD system. Samples were stored in the dark in pre-cleaned 10-1 canisters until further preparation.

Pre-filtered samples (GFF, precombusted at $450{ }^{\circ} \mathrm{C}$ for $2 \mathrm{~h}$ ) were ultra-filtered using a cross-flow filtration system from Millipore with 2 Pellicon 2 cartridges (cut-off $1 \mathrm{kD}$ ). The cross-flow ratio (retentate-to-permeate flux, CFR) was kept well above 15 according to the advice given in the study of Larsson et al. (2002). After the ultra-filtration step, the samples were frozen immediately in $500 \mathrm{ml}$ PETG bottles at $-20^{\circ} \mathrm{C}$ and freeze-dried. The freeze-dried material was weighted into silver caps, after acidification with $0.1 \mathrm{M} \mathrm{HCl}$ and subsequent drying. Determination of stable isotope ratios was done in a Thermo Finnigan Delta V Advantage mass spectrometer, after combustion in a Carlo Erba NC2500 elemental analyzer at $1020^{\circ} \mathrm{C}$. The $\delta^{13} \mathrm{C}$ values are reported in \%o relative to relative to Pee Dee Belemnite (PDB); the used IAEA reference materials were CO-1, CO-8, NBS18, and NBS 19. Peptone was used as internal lab standard. The analytical precision is $\pm 0.2 \%$.

Samples for DOC analysis were taken from the pre-filtered sample as well as from retentate and permeate after the ultrafiltration step to allow a recovery calculation. DOC analyses were done by high-temperature catalytic oxidation with a Shimadzu TOC-VCPH. Inorganic carbon was removed by acidifying the samples with $\mathrm{HCl}$ to $\mathrm{pH}$ 2. The DOC recovery during the ultrafiltration step was calculated for every station, ranged between $13.1-27.3 \%$, and showed no correlation to salinity $\left(r^{2}=0.02\right)$.

For analysis of the $\delta^{18} \mathrm{O}-\mathrm{H}_{2} \mathrm{O}$ values, sub-samples were taken from the pre-filtered water samples. Analyses were done either in a Thermo Finnigan Delta V Advantage after thermo-conversion in a TCEA at $1350^{\circ} \mathrm{C}$ via ConFlo IV or in a Los Gatos LWIA (liquid water isotope analyzer). The used reference materials were SMOW, GISP, and SLAP. The values are reported relative to VSMOW and the analytical precision is $\pm 0.2 \%$.

\subsection{Data evaluation}

To evaluate if the DOC distribution in the Baltic Sea is determined by mixing or by production and degradation processes, we calculated a theoretical mixing curve for $\delta^{13} \mathrm{C}$ DOC, which we compared with our measured $\delta^{13} \mathrm{C}-\mathrm{HMW}-$ DOC values. This was done for all stations east of the Darss Sill, and the end-members we used for the calculation were the two stations, which showed the lowest and highest salinity. The used equations are described in Fry (2002) and were slightly modified by Kaldy et al. (2005).

In a second approach we wanted to estimate the share of terrestrial DOC in the various basins of the Baltic Sea east of the Darss Sill. Therefore we applied an 


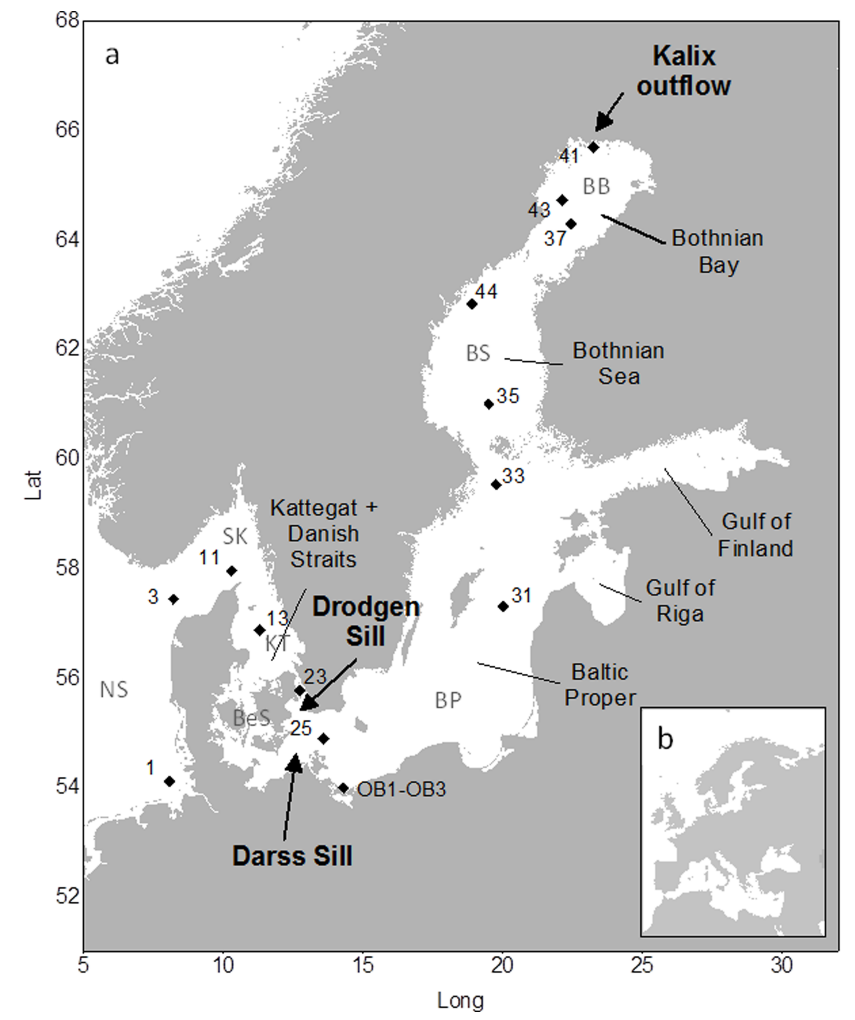

Fig. 1. Map (a) showing all stations from the German Bight (North Sea) to the Kalix River mouth (Baltic Sea). The insert (b) shows the location of the Baltic Sea in Europe.

end-member-mixing-model-analysis (EMMA) by means of the $\delta^{13} \mathrm{C}$-HMW-DOM values. For the terrestrial DOC $\left(\delta^{13} \mathrm{C}_{t e r}\right)$ the used end-member (EM) was an average $\delta^{13} \mathrm{C}$ value of HMW-DOM from the Kalix River collected during 4 sampling campaigns from April to October 2010 $(-27.1,-27.9,-28,5,-28.7 \%$ o, MW $=-28.1 \pm 0.7 \%$ o $)$. This value well reflects the typical $\delta^{13} \mathrm{C}$ values of terrestrial organic matter measured in other river systems (e.g. Kaldy et al., 2005 and references therein; Van den Meersche et al., 2009; Humborg et al., unpublished) and is in our opinion valid for terrestrial inputs via rivers throughout the whole Baltic Sea area. In their review article Raymond and Bauer (2001) present $\delta^{13} \mathrm{C}$ values of riverine DOC ranging from -24.6 to $-32.4 \%$ o. Although the $\delta^{13} \mathrm{C}$ values they present cover a wide range, many of the rivers presented in their publication show $\delta^{13} \mathrm{C}$ values of DOC around $-28 \%$ o or lower (e.g. Amazon: $-28.0 \%$, York: -28.8 to $-27.9 \%$, Parker: -28.3 to $-29.0 \%$ ).

Finding a suitable end-member for the marine/autochthonous DOM component in the Baltic Sea was more challenging, since the phytoplankton in the Baltic Sea show different $\delta^{13} \mathrm{C}$ values depending on the $\delta^{13} \mathrm{C}$ value of the DIC which they used as carbon source. This is then also mirrored in the $\delta^{13} \mathrm{C}$ values of the DOC released by the phytoplankton cells. We used the average $\delta^{13} \mathrm{C}$ values of Baltic Sea phytoplankton (size fraction 5-100 $\mu \mathrm{m}$ ) sampled in the different basins which are reported from Rolff and Elmgren (2000) to calculate an average $\delta^{13} \mathrm{C}$ value for phytoplankton from the Baltic Sea. This calculated average value $(-23.1 \%$ ) was used as end-member for marine/autochthonous DOM $\left(\delta^{13} \mathrm{C}_{\mathrm{aut}}\right)$.

The share of terrestrial DOC $\left(f_{\text {ter }}\right)$ at every station was calculated with the formula:

$f_{\text {ter }}=\left(\delta^{13} \mathrm{C}_{\text {sample }}-\delta^{13} \mathrm{C}_{\mathrm{aut}}\right) /\left(\delta^{13} \mathrm{C}_{\mathrm{ter}}-\delta^{13} \mathrm{C}_{\mathrm{aut}}\right)$,

with $\delta^{13} \mathrm{C}_{\text {sample }}=\delta^{13} \mathrm{C}$ value of the sample at the certain station.

The calculated share of terrestrial DOC at each sampled station was then compared to the share of freshwater (\% freshwater), which we calculated with an additional EMMA by means of the $\delta^{18} \mathrm{O}-\mathrm{H}_{2} \mathrm{O}$ values. The end-members we used for this calculation were the $\delta^{18} \mathrm{O}$ value for full marine waters of $0 \%$ (Craig and Gordon, 1965) and a calculated discharge-weighted average $\delta^{18} \mathrm{O}-\mathrm{H}_{2} \mathrm{O}$ value for river water draining into the Baltic Sea $\left(-11.7 \%\right.$ ). The $\delta^{18} \mathrm{O}-\mathrm{H}_{2} \mathrm{O}$ data for the calculation of this average value were taken from a study of Burgman et al. (1987). The discharge data were obtained from the Baltic Environmental Database (BED). The used end-members for all calculations are summarized in Table 1 .

\section{Results and discussion}

\subsection{Use of $\delta^{18} \mathrm{O}-\mathrm{H}_{2} \mathrm{O}$ to characterize the different water bodies}

At station 1 a salinity of 31.8 was observed which slightly increased to the maximum value of 34.3 at station 3 and then decreased continuously to 1.9 close to the Kalix River mouth (station 41). Our sampled stations in the Oder Bight showed salinities from 4.1 to 6.8 . By plotting the measured $\delta^{18} \mathrm{O}$ $\mathrm{H}_{2} \mathrm{O}$ values against the salinities, it becomes obvious that we found two different water bodies along our sampled gradient (Fig. 2). The first covers our sampled stations 1 to 25 which are the German Bight, Skagerrak, Kattegat and Belt Sea and the second all stations east of the Darss Sill with exception of the 3 stations in the salinity gradient of the Oder Bight, where no relation between salinity and $\delta^{18} \mathrm{O}-\mathrm{H}_{2} \mathrm{O}$ is visible. Since the sampling in the Oder Bight occurred early in the year shortly after the melting of the ice in the Oder lagoon, we assume an influence of the meltwater here. The difference in the water bodies is expressed in a change of the slope and reflects the high proportion of a high latitude freshwater input into the central and northern parts of the Baltic Sea, which are characterized by lower $\delta^{18} \mathrm{O}-\mathrm{H}_{2} \mathrm{O}$ values compared to the freshwater inputs into the western parts of the Baltic Sea, which have slightly higher $\delta^{18} \mathrm{O}-\mathrm{H}_{2} \mathrm{O}$ values. A similar $\delta^{18} \mathrm{O}-\mathrm{H}_{2} \mathrm{O}$ vs. salinity pattern in the Baltic Sea is also reported in the study of Fröhlich et al. (1988), however 
Table 1. Used end-member for the different mixing-model approaches which were applied.

\begin{tabular}{lll}
\hline Mixing model used to & $\begin{array}{l}\text { High salinity end-member } \\
\text { (marine/autochthonous) }\end{array}$ & $\begin{array}{l}\text { Low salinity end-member } \\
\text { (freshwater/terrestrial) }\end{array}$ \\
\hline $\begin{array}{l}\text { Check isotope data for mixing } \\
\text { Calculate the share of } \mathrm{DOC}_{\text {ter }}\end{array}$ & $\begin{array}{l}\delta^{13} \mathrm{C}=-25.3 \% \text { (own data) } \\
\delta^{13} \mathrm{C}=-23.1 \% \text { (calculated from Rolff } \\
\text { and Elmgren, 2000) }\end{array}$ & $\begin{array}{l}\delta^{13} \mathrm{C}=-27.3 \% \text { (own data) } \\
\delta^{13} \mathrm{C}=-28.1 \% \text { (own data) }\end{array}$ \\
Calculate the share of freshwater & $\delta^{18} \mathrm{O}-\mathrm{H}_{2} \mathrm{O}=0 \%$ (calculated from \\
& & $\begin{array}{l}\delta^{18} \mathrm{O}-\mathrm{H}_{2} \mathrm{O}=-11.7 \% \text { (c) } \\
\text { Burgman et al., 1987) }\end{array}$ \\
\hline
\end{tabular}

not as pronounced as in this study. Rivers draining into the Bothnian Bay and Bothnian Sea show average $\delta^{18} \mathrm{O}-\mathrm{H}_{2} \mathrm{O}$ values $<-12 \%$, whereas the values are $\geq-10 \%$ for rivers draining into the Baltic Proper (Burgman et al., 1987). Between the Darss Sill and the adjacent Arkona Basin (Station 25, Fig. 1), the two water bodies meet. Surprisingly there is no real transition zone visible between the two water bodies but an abrupt change. The exceptional function of the shallow entrance parts of the Baltic Sea for the water exchange between the North Sea and the central Baltic Sea is well investigated (e.g. Lass et al., 2005), and strongly influences the water residence times which are calculated to be $0.2 \mathrm{yr}$ in the Danish Straits west of the Darss Sill and $4.4 \mathrm{yr}$ in the adjacent Baltic Proper (Savchuk, 2005). Based on our $\delta^{18} \mathrm{O}-\mathrm{H}_{2} \mathrm{O}$ measurements, we decided to use only the data set with salinities $<7.5$ (all stations east of station 25) for further investigations about distribution of terrestrial dissolved organic matter within the Baltic Sea ecosystem. To avoid a mix up of data from different systems, the used dataset includes the stations 31-41 and the gradient in the Oder Bight (OB1-OB3).

\subsection{DOC concentrations and $\delta^{13} \mathrm{C}$ values of HMW-DOC}

The relationship between salinity and the DOC concentrations as well as salinity and $\delta^{13} \mathrm{C}$-HMW-DOC is shown in Fig. 3. The DOC concentrations ranged from 273 to $351 \mu \mathrm{moll}^{-1}$ and showed only a weak correlation with salinity (Fig. 3a, mean absolute percentage error $(\mathrm{MAPE})=5.39 \%)$. As expected the concentrations were highest close to the Kalix River estuary and lowest in the stations of the open Baltic. The lowest concentration was measured in the northernmost station of the Oder Bight gradient. In contrast to DOC the $\delta^{13} \mathrm{C}$ values of the HMW-DOM showed a very good relationship to salinity (Fig. 3b, MAPE $=1.12 \%$ ). The isotope data indicate a change in the composition of the DOM from a more terrestrial source at lower salinities, which reflects C-3 based carbon fixation with values lower than $-27 \%$, to a more marine/autochthonous source with higher $\delta^{13} \mathrm{C}$ values around $-24.5 \%$ at higher salinities. Benner et al. (1997) report $\delta^{13} \mathrm{C}$ values for marine DOM from the Pacific and Atlantic Ocean and the Gulf of Mexico in a narrow range from -22.2 to $-21.7 \%$. Another study from the Gulf of Mexico presents $\delta^{13} \mathrm{C}$ values of HMW-DOM between -22.7 and $-20.9 \%$ at salinities $>35$ and decreasing $\delta^{13} \mathrm{C}$ values with decreasing salinities similar to our study (Guo et al., 2003). Inside the Trinity River (salinity $<5$ ) $\delta^{13} \mathrm{C}$ values lower than $-25.5 \%$ o were recorded, reflecting a higher influence of terrestrial organic material. Lower $\delta^{13} \mathrm{C}$ values of HMW-DOM were also reported from the Potomac River $(-27.3$ to $-24.0 \%$ ), the Chesapeake Bay ( -27.8 to $-23.5 \%$ ) and the San Francisco Bay ( -27.8 to $-26.0 \%$ ) (Sigleo and Macko, 2002), as well as for the Mississippi River plume (Guo et al., 2009) and the Pamunkey River (McCallister et al., 2006). In the Scheldt River and estuary, $\delta^{13} \mathrm{C}$-DOC values ranging from around -25 to lower than $-30 \%$ o have been measured (Van den Meersche et al., 2009). In the Altamaha and Satilla estuaries in southeastern USA, a gradient in the DOC concentrations and in the $\delta^{13} \mathrm{C}$ values of the DOC and the humic acid (HS) fraction was observed by Otero et al. (2003). Higher DOC concentrations as well as lower $\delta^{13} \mathrm{C}$-DOC and $\delta^{13} \mathrm{C}$ HS were measured close to the river mouth. The $\delta^{13} \mathrm{C}$-DOC values ranged from -25.3 to $-19 \%$ in the Altamaha estuary and slightly lower in the Satilla estuary ( -27 to $-21 \%$ ). Whereas both the $\delta^{13} \mathrm{C}$-DOC and the $\delta^{13} \mathrm{C}$-HS values closely followed the conservative mixing line in the Altamaha estuary, strong deviations from the mixing line could be observed for the $\delta^{13} \mathrm{C}$-DOC values in the Satilla estuary. The authors explained these differences with an addition of a non-humic estuarine-produced DOC as a result of the longer water residence times in the Satilla estuary compared to the Altamaha estuary.

As seen from Fig. 3b, the values deviate slightly from the calculated mixing curve. This can be a result of the methodological precision but might also indicate that not only mixing determines the HMW-DOC distribution in the Baltic Sea. Since most of the $\delta^{13} \mathrm{C}$ values are slightly higher than the mixing line, we assume a slight addition of DOC from marine sources which will be mainly phytoplankton-released DOC. This seems to be likely, since most stations were sampled during the summer months when primary production reaches its seasonal maximum. The maximum difference in the $\delta^{13} \mathrm{C}$ values between the calculated values for mixing and the measured values is however only $0.5 \%$, which indicates a minor contribution of DOC from phytoplankton release. This seems to be reasonable since it is known that large parts 


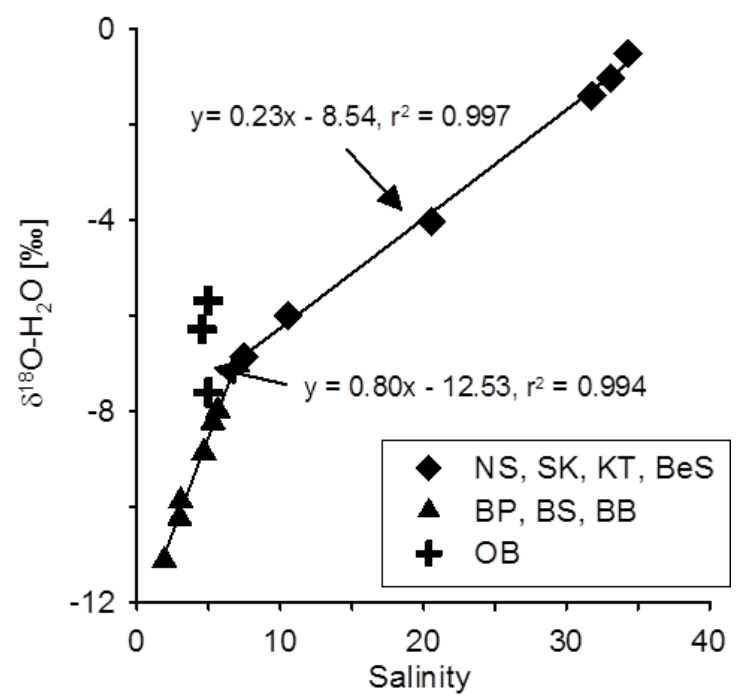

Fig. 2. $\delta^{18} \mathrm{O}-\mathrm{H}_{2} \mathrm{O}$ values plotted versus salinity for the three different groups of stations (diamonds: North Sea (NS), Skagerrak (SK), Kattegat (KT), and Belt Sea (BeS); triangles: Baltic Proper (BP), Bothnian Sea (BS), Bothnian Bay (BB), crosses: Oder Bight (OB)).

of fresh DOC recently released from phytoplankton can be highly bioavailable and accessible (Norrman et al., 1995), which implies that it will not accumulate.

If we compare our measured DOC concentrations with the calculated DOC concentrations from the mixing equations, it can be observed that nearly all stations show a lower measured DOC concentration than calculated (maximum difference is $44 \mu \mathrm{mol}^{-1}$ at station 44 ). Besides the fact that there is always an influence from the analytical precision of our applied methods (stable isotope analysis: $\pm 0.2 \%$, DOC analysis: $5 \%$ ), it can be assumed that there exists another process, which reduces the DOC concentrations without being visible in the $\delta^{13} \mathrm{C}$ values. Degradation of organic matter might be a possible one since it is still not known to what extent it influences the $\delta^{13} \mathrm{C}$ values of the residual DOM. Whereas Macko and Estep (1984) could show in laboratory experiments that microbial DOM uptake can influence the $\delta^{13} \mathrm{C}$ values of the residual DOM, data from terrestrial systems indicate that isotope fractionation associated with DOM degradation might be low. For the Baltic river Luleälven, Humborg et al. (unpublished) could not detect any significant change in $\delta^{13} \mathrm{C}$ HMW-DOC ( -26.6 to $-28.2 \%$ ) even if it is known from $\mathrm{CO}_{2}$ measurements that this river is oversaturated with $\mathrm{CO}_{2}$ because of DOC respiration indicating a degradation as high as $50 \%$ (Humborg et al., 2010).

\subsection{What happens to HMW-DOC ter $_{\text {in }}$ the Baltic Sea?}

To evaluate the fate of terrestrial DOM within the Baltic Sea ecosystem and to check for HMW-DOM degradation, we used the calculated share of terrestrial DOC $\left(\mathrm{DOC}_{\mathrm{ter}}\right)$ from the EMMA (Fig. 4) to calculate the concentration of $\mathrm{DOC}_{\text {ter }}$
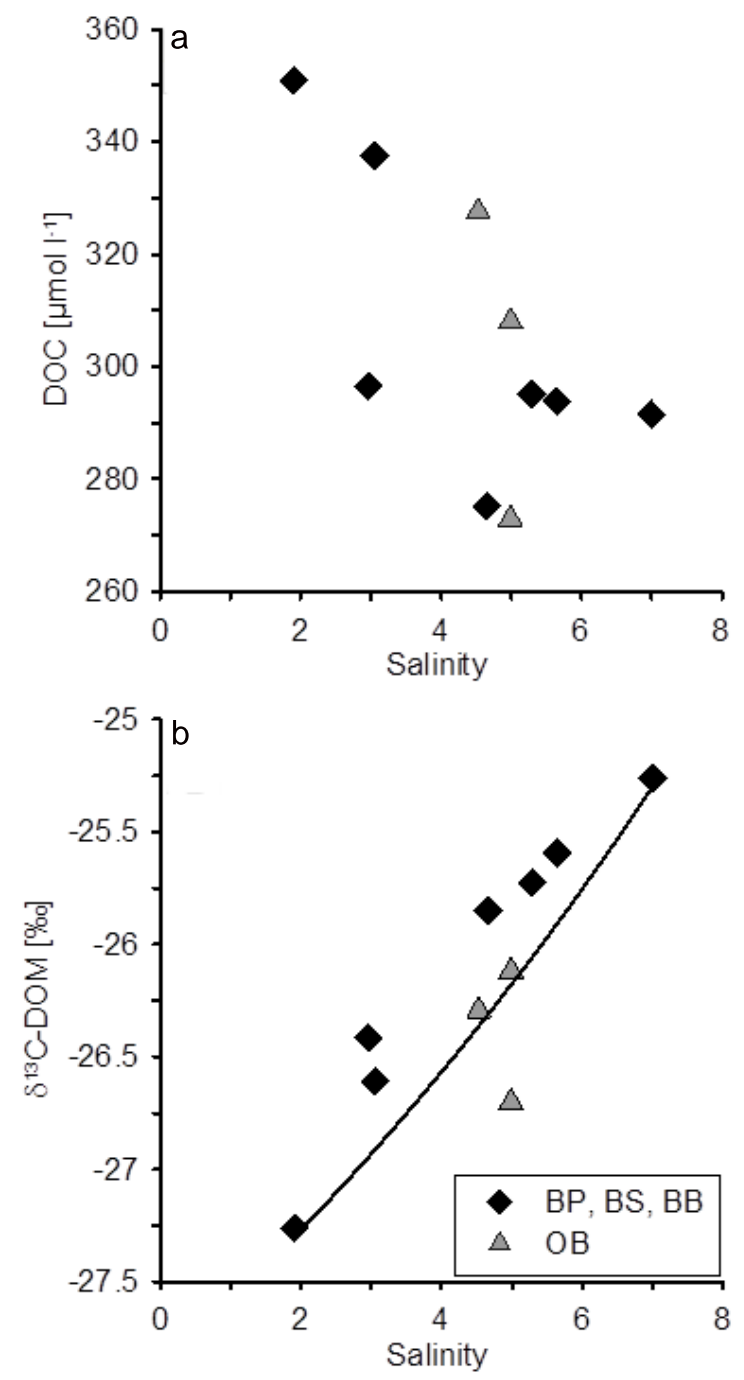

Fig. 3. DOC concentrations (a) and $\delta^{13} \mathrm{C}$ values of HMW-DOM (b) plotted versus salinity for all stations in the salinity range between 0-7.5. The black diamonds show the stations sampled in the Baltic Proper, Bothnian Sea, and Bothnian Bay during the cruise with $\mathrm{r} / \mathrm{v}$ Maria S. Merian, and the grey triangles represent the station in the Oder Bight.

at each of our investigated stations, assuming that the share of HMW-DOM to the total DOM pool is constant throughout all sampled stations. The contribution of $\mathrm{DOC}_{\text {ter }}$ to the total DOC ranged from 40 to $80 \%$. The lowest percentage was found at station 31 , which was the station with the highest salinity, and the highest was found at station 41 closest to the Kalix River mouth. The calculated concentrations of $\mathrm{DOC}_{\mathrm{ter}}$ ranged from 125 to $292 \mu \mathrm{mol}^{-1}$ and show a linear correlation with salinity (Fig. $5 \mathrm{a}$, yr $=-29.44 \times+321.88, r^{2}=0.73$, $p<0.002)$. This indicates that the $\mathrm{DOC}_{\text {ter }}$ is not subject to an intensive removal once it reaches the open Baltic Sea. If we add the annual average discharge-weighted DOC concentration of the Kalix River $\left(519 \mu \mathrm{mol}^{-1}, 1996-2000\right.$, source: 
monthly monitoring data) to Fig. 5a, we see that the linear correlation is no longer visible anymore, which indicates a removal of the terrestrial organic matter directly in the estuary. However, only station 41 might be directly influenced only by water from the Kalix River, whereas all the other stations sampled in the Bothnian Bay show a mixture of DOC which derived from various rivers draining into this basin. If we add an average discharge-weighted DOC concentration for all rivers draining into the Bothnian Bay, which is estimated to be around $624 \mu \mathrm{moll}^{-1}$ (source: monthly monitoring data, Baltic Nest Institute), to Fig. 5a, the removal of the $\mathrm{DOC}_{\text {ter }}$ in the estuaries becomes more distinct. In total around $390 \mu \mathrm{mol}$ DOC, which is $>50 \%$ of the input, are removed within this salinity range. A common feature of the rivers draining into the northern parts of the Baltic Sea is a pronounced spring peak, where large amounts of DOC were transported to the Baltic together with the melting water during a very short period. Therefore it can be assumed that the removal of $\mathrm{DOC}_{\text {ter }}$ within the estuaries varies strongly throughout the year. However since the material we sampled at the central stations of the Baltic Sea is at least several months old and represents a mixture of several estuaries, the spring peak flow events will not influence our results to such a great extent.

Benner and Amon (1996) developed the conceptual "size reactivity continuum model" which implies that the bioreactivity of dissolved organic matter decreases with decreasing size of the compounds. They suggest that the HMWDOM is the more fresh material, whereas the low molecular weight (LMW) DOM is more diagenetically altered. The model theory was proven by several other studies (Sulzberger and Durisch-Kaiser, 2009, and references therein); however, there were other studies showing contradictory results (e.g. Rochelle-Newall et al., 2004; Rosenstock et al., 2005). In our data we could not find a correlation between salinity and the calculated DOM recovery, which could be used as an indicator of a change in the size of the DOM. Therefore it is not visible from our data if a similar pattern as reported from Benner and Amon (1996) exists. However it might be possible at salinities lower than 1.9 that differences in the ratio of HMW-DOM to LMW-DOM could be observed.

A similar removal pattern as found in our study was also reported for the Arctic region in the studies of Alling et al. (2010) and Letscher et al. (2011). For the Lena River discharge on the East Siberian Arctic Shelf, Alling et al. (2010) calculated a DOC removal of up to $50 \%$ before reaching the high salinity areas of the central Arctic Ocean giving a firstorder removal rate constant of $0.3 \mathrm{yr}^{-1}$. This rate was confirmed $(0.24 \pm 0.08)$ by a study in the Makarov and Eurasian basin in the Arctic by Letscher et al. (2011). They observed a linear correlation between salinity (range 26 to 34 ) and the DOC concentration, and used their correlation together with an annual mean DOC concentration for the Arctic rivers to calculate a loss of $400 \mu \mathrm{moll}^{-1}$ DOC over the Arctic shelf system.

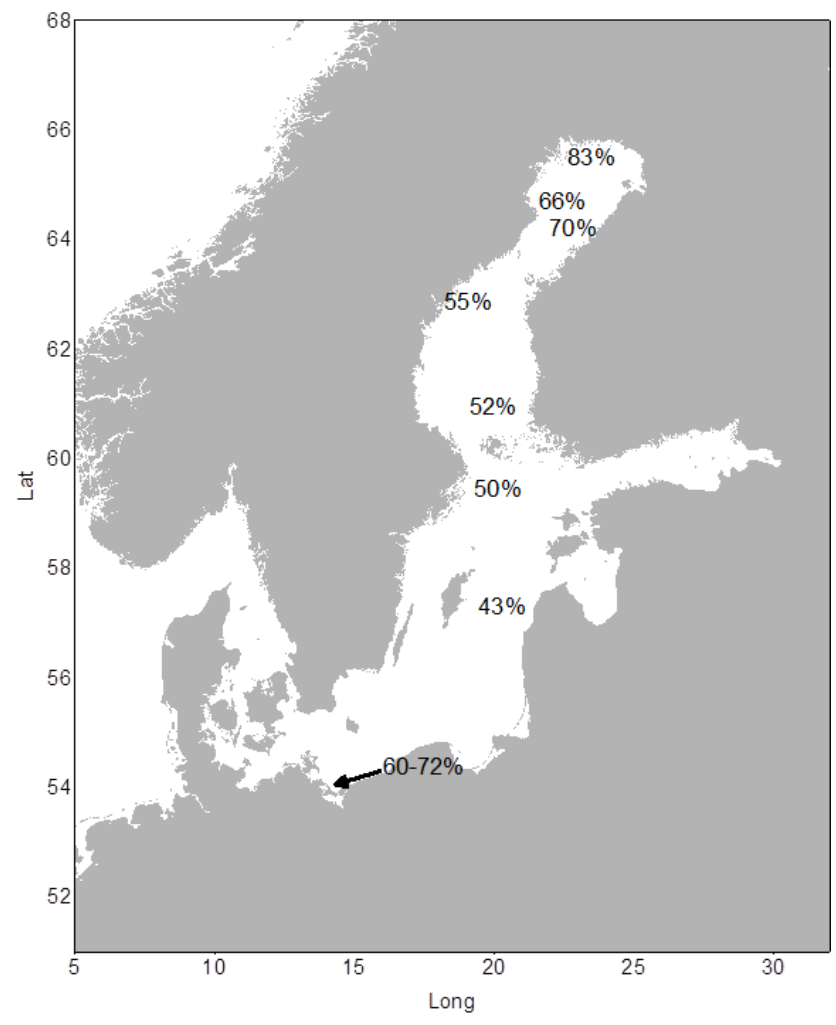

Fig. 4. Results from the EMMA approach showing the calculated proportions of terrestrial DOC in percent.

Interestingly, the contribution of terrestrial DOC does not fall below $43 \%$ level even in the central basins of the Baltic Sea, which confirms the high influence of the terrestrial landscape to the ecosystem of the Baltic Sea. This indicates how strong a climate-related increase of the terrestrial DOM input might influence the biogeochemistry of this ecosystem.

Overall our results are in very good agreement with the results from Alling et al. (2008) where the $\delta^{34} \mathrm{~S}$ values of DOS were used to calculate the share of DOS $_{\text {ter }}$ in the central and northern Baltic Sea. Both studies calculated more or less exactly the same amount of terrestrial organic matter for the Baltic Proper $(\sim 40 \%)$, the Bothnian Sea $(\sim 50 \%)$ and the Bothnian Bay $(\sim 70-80 \%)$. However larger differences appear if Alling et al. (2008) convert their contributions from DOS to DOC by using C:S ratios for terrestrial and marine organic matter from literature. After the conversion Alling et al. (2008) report higher shares of DOC $\mathrm{C}_{\text {ter }}$ compared to our calculations. A reason for the observed differences in the calculated share of $D C_{\text {ter }}$ might be caused by different sampling seasons. Whereas Alling et al. (2008) sampled during winter, our samples were taken during late summer, which makes a higher contribution of autochthonous DOC most likely. However also the choice of an appropriate $\mathrm{C}: \mathrm{S}$ ratio for the conversion of the DOS to the DOC can be a crucial point. 


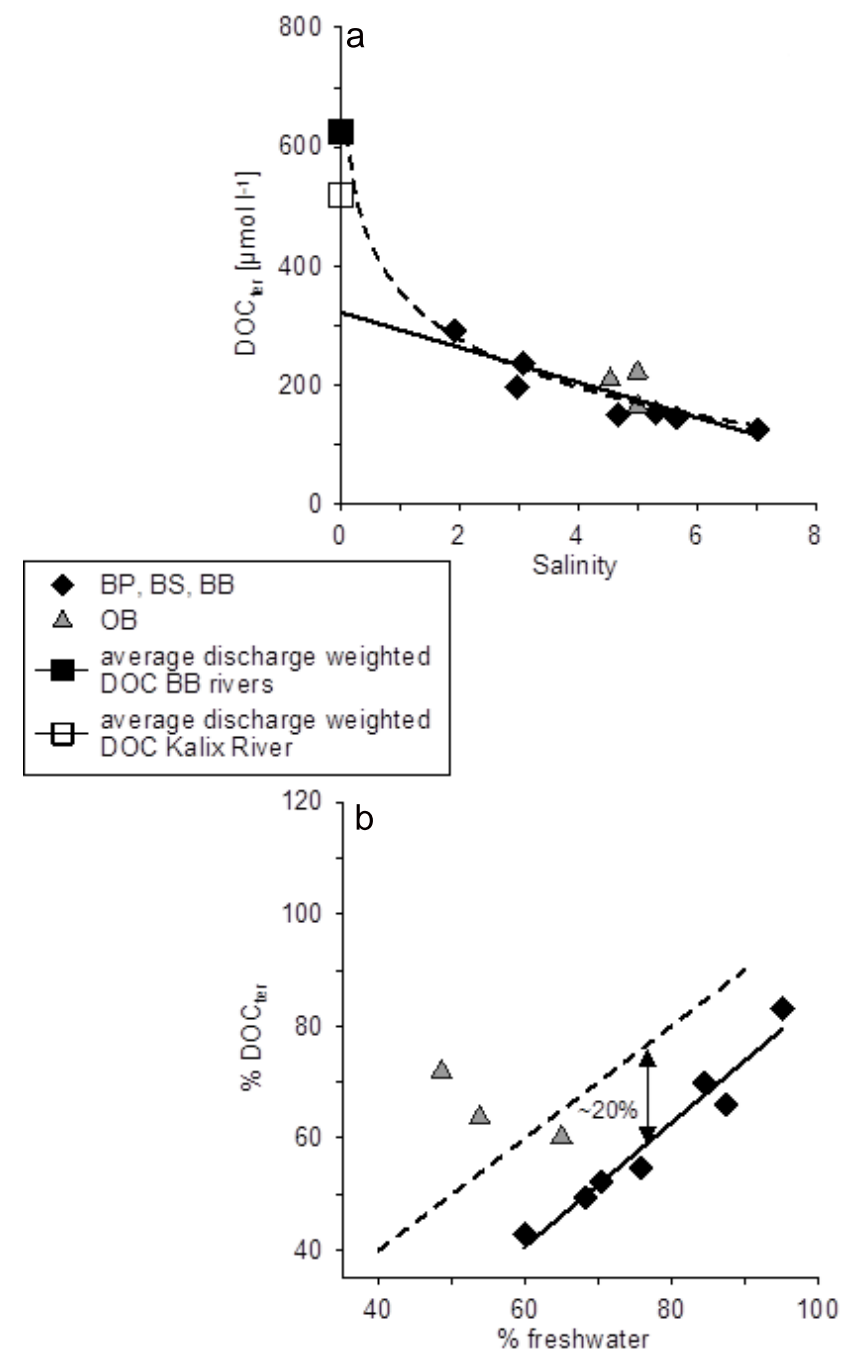

Fig. 5. The calculated $\mathrm{DOC}_{\text {ter }}$ concentrations plotted versus salinity (a) together with the average discharge-weighted DOC concentration of the Kalix River (open square) and of all rivers draining into the Bothnian Bay (black square). The solid line represents the linear fit for all samples without the average river DOC concentration, the dashed line the logarithmic fit for all samples with the average river DOC concentration. Plot (b) shows the calculated share of DOC versus the share of freshwater. The dashed line represents the 1:1 line; the solid line is the linear fit. The symbols are the same used in Fig. 3.

In an additional approach to evaluate the possible processes that determine the DOM distribution in the Baltic, we calculated the share of freshwater for each of our stations by means of the $\delta^{18} \mathrm{O}-\mathrm{H}_{2} \mathrm{O}$ values and plotted it against the calculated share of $\mathrm{DOC}_{\text {ter }}$ (Fig. 5b). Assuming that the DOM distribution in the Baltic Sea is only determined by mixing the plotted values should more or less follow the 1:1 line, whereas all deviations from this line should point to other processes that might influence the DOM distribution like degradation or phytoplankton DOC release. Inter- estingly, the samples from the Baltic Proper, Bothnian Sea, and Bothnian Bay (31-44) show a linear correlation between the percentage of freshwater and the percentage of $\mathrm{DOC}_{\text {ter }}$ with a slope close to 1 but an offset $(\sim 20 \%)$ from the $1: 1$ line, whereas the three samples of the Oder Bight transect showed no correlation between the percentage of freshwater and $\mathrm{DOC}_{\text {ter. }}$. The parallel curse indicates in our opinion that once the $\mathrm{DOC}_{\text {ter }}$ has reached the open waters it is not subject to significant removal anymore. The $20 \%$ offset between the stations and the 1:1 line however indicate that either removal occurred before the $\mathrm{DOC}_{\text {ter }}$ reached the open Baltic Sea or that a constant addition of autochthonous DOM took place. Both processes seem to be likely during the sampled season and might have occurred parallel, but since we could not detect a significant input of DOC from phytoplankton by means of our $\delta^{13} \mathrm{C}$ mixing calculations, we favor $\mathrm{DOC}_{\text {ter }}$ removal within the estuaries as responsible process. What remains unclear however is the reason for the observed difference between the $>50 \% \mathrm{DOC}_{\text {ter }}$ removal, which we calcu-

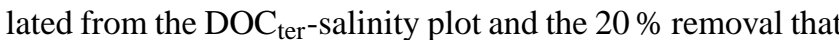
was calculated from Fig. 5b. Since both calculations use the same calculated share of $\mathrm{DOC}_{\text {ter }}$ as basis, only the choice of the $\delta^{18} \mathrm{O}-\mathrm{H}_{2} \mathrm{O}$ end-member values for the freshwater EMMA influences the offset between the calculated shares of freshwater and $\mathrm{DOC}_{\text {ter. }}$. Whereas the $\delta^{18} \mathrm{O}-\mathrm{H}_{2} \mathrm{O}$ values in surface waters of the North Sea and northern Atlantic show only little variation $(-0.5$ to $+0.3 \%$, source: Schmidt et al., 1999, Global Seawater Oxygen-18 Database - v1.21) and therefore our chosen end member of $0 \%$ seems reliable, the $\delta^{18} \mathrm{O}$ values in the river water cover a wider range. However even if we modify the freshwater end-member in our freshwater EMMA to lower (higher freshwater input from high latitude rivers) or higher (higher freshwater input from low latitude rivers) $\delta^{18} \mathrm{O}$ values (Burgman et al., 1987), the general pattern with the parallel curve - indicating no major $\mathrm{DOC}_{\text {ter }}$ removal in the open Baltic - shown in Fig. $5 b$ is still visible.

\subsection{A HMW-DOC budget for the central and northern Baltic Sea}

Based on our measured concentrations and the calculated share of $\mathrm{DOC}_{\text {ter }}$, we calculated a DOC budget for the Baltic Proper, the Bothnian Sea and the Bothnian Bay (Table 2). The DOC stocks were calculated for each basin by multiplying the average DOC concentration with the water volume of the respective basin. To calculate the DOC stock for the Gulf of Finland, the DOC concentration $\left(300 \mu \mathrm{mol}^{-1}\right)$ was taken from Pitkänen et al. (2008). The $\mathrm{DOC}_{\text {ter }}$ stocks were calculated by using the average share of $\mathrm{DOC}_{\text {ter }}$ to total DOC. The transport of DOC between the basins was calculated by using the water budget of the Baltic Sea presented in Savchuk (2005). Import of DOC from the Gulf of Riga to the Baltic Proper could not be incorporated into the budget because of a lack of DOC data from the Gulf of Riga. To calculate the import of $\mathrm{DOC}_{\text {ter }}$ from the Gulf of Finland and the 
Table 2. DOC budget for 3 Baltic Sea basins.

\begin{tabular}{|c|c|c|c|c|c|c|c|c|c|c|}
\hline Basin & $\begin{array}{l}\text { average DOC } \\
{\left[\mu \mathrm{mol} 1^{-1}\right]}\end{array}$ & $\begin{array}{l}\text { DOC stock } \\
{[\mathrm{kg}]}\end{array}$ & $\begin{array}{l}\text { DOC }_{\text {ter }} \\
{[\%]}\end{array}$ & $\begin{array}{l}\text { stock DOC } \text { ter }_{\text {t }} \\
{[\mathrm{kg}]}\end{array}$ & $\begin{array}{l}\text { DOC }_{\text {ter import from }} \\
\text { other Basins }[\mathrm{kg}]\end{array}$ & $\begin{array}{l}\text { riverine DOC } \\
\text { inputs }[\mathrm{kg}]\end{array}$ & $\begin{array}{l}\text { atm. DOC } \\
\text { input }[\mathrm{kg}]\end{array}$ & $\begin{array}{l}\text { point source DOC } \\
\text { inputs }[\mathrm{kg}]\end{array}$ & $\begin{array}{l}\Sigma \mathrm{DOC}_{\text {ter }} \\
\text { input }[\mathrm{kg}]\end{array}$ & $\begin{array}{l}\text { residence time } \\
\mathrm{DOC}_{\text {ter }}[\mathrm{yrs}]\end{array}$ \\
\hline Bothnian Bay & 307.6 & $5.02 \mathrm{E}+09$ & 68 & $3.41 \mathrm{E}+09$ & $4.01 \mathrm{E}+08$ & $6.99 \mathrm{E}+08$ & $4.16 \mathrm{E}+07$ & $6.17 \mathrm{E}+07$ & $1.20 \mathrm{E}+09$ & 2.8 \\
\hline Bothnian Sea & 316.4 & $1.72 \mathrm{E}+10$ & 61 & $1.05 \mathrm{E}+10$ & $2.81 \mathrm{E}+09$ & $5.93 \mathrm{E}+08$ & $8.31 \mathrm{E}+07$ & $6.45 \mathrm{E}+07$ & $3.56 \mathrm{E}+09$ & 3.0 \\
\hline Baltic Proper & 298.8 & $5.34 \mathrm{E}+10$ & 58 & $3.08 \mathrm{E}+10$ & $5.35 \mathrm{E}+09$ & $1.04 \mathrm{E}+09$ & $2.59 \mathrm{E}+08$ & $1.67 \mathrm{E}+08$ & $6.81 \mathrm{E}+09$ & 4.5 \\
\hline
\end{tabular}

Danish Straits to the Baltic Proper, we assumed a share of $\mathrm{DOC}_{\mathrm{ter}}$ of $60 \%$ and $50 \%$ for the respective basin. The riverine inputs of DOC were taken from monitoring data (source: Baltic Nest Institute). Atmospheric inputs of DOC to the different basins were calculated with average DOC concentrations $\left(210 \mu \mathrm{mol}^{-1}\right)$ measured in rainwater of 9 sites in Sweden (Neumann et al., 1959), the average annual precipitation in offshore areas of the Baltic Sea $(450 \mathrm{~mm})$ reported by Bergström et al. (2001) and the size of the respective Baltic Sea areas. Point source emissions of TOC were calculated by conversion of BOD7 (biological oxygen demand) values obtained from the "Fourth Baltic Sea Pollution Load Compilation" (Helcom, 2004) as described in Algesten et al. (2006) and Kuliński and Pemkowiak (2011). According to Helcom (1983) the BOD7 value was divided by the conversion rate of 2.27 to calculate the point source input of TOC. To convert the TOC concentration to DOC, we used a DOC : TOC ratio of 0.9. The total input of $\mathrm{DOC}_{\text {ter }}$ was calculated, and together with the stock of $\mathrm{DOC}_{\text {ter }}$ it was possible to calculate the residence time of $\mathrm{DOC}_{\text {ter }}$ for the Bothnian Bay, the Bothnian Sea and the Baltic Proper which was 2.8, 3.0 and $4.5 \mathrm{yr}$, respectively. These residence times are shorter compared to those reported from Alling et al. (2008), who calculated residence times for $\mathrm{DOC}_{\text {ter }}$ of 3.7 and $3.5 \mathrm{yr}$ for the Bothnian Bay and the Bothnian Sea, respectively. In agreement with the study of Alling et al. (2008), our calculated residence times are lower than the water residence times for these basins (5.1, 3.2, and $4.4 \mathrm{yr}$ for Bothnian Bay, Bothnian Sea and Baltic Proper, respectively) calculated by Savchuk (2005). This indicates that a high $\mathrm{DOC}_{\text {ter }}$ retention must take place. Since we could show that no or only little changes of the $\mathrm{DOC}_{\mathrm{ter}}$ pool occur in the open Baltic Sea, DOC removal must take place in close vicinity to the coasts, e.g. in the river estuaries.

Our finding that most of the terrestrial DOC must be retained within the river estuaries is also supported by the results of Korth et al. (2011), who calculated a high DON turnover rate of $42 \mathrm{~h}$ for the Baltic Sea and concluded that due to these high rates riverine DON is mainly degraded in close proximity to the coasts and that the refractory compounds are transported to the open basins.

\section{Conclusions}

Overall, our results demonstrate the high importance of the terrestrial DOM inputs for the Baltic Sea ecosystem. We were able to supplement the results from the study of Alling et al. (2008) by providing additional data for an additional Baltic Sea Basin from a different season. By comparing the results from both studies, it becomes obvious that there are some differences in the distribution and behavior of terrestrial DOM between winter and summer. Furthermore, we could point out that the high DOM removal, which was also proposed by Alling et al. (2008), does not takes place in the open Baltic Sea, but must happen in the estuaries, which seem to play an important role in regulating how much DOM reaches the open Baltic Sea. Even if the material we found in the open Baltic Sea is not subject to intensive removal anymore, it is still there, and an increased input of terrestrial DOM due to climate change will lead to a further enrichment of this unused material. Furthermore, it is unclear how much of this material is removed over longer timescales.

Acknowledgements. The authors would like to thank Heike Siegmund from SIL at Stockholm University for analysis of the stable isotope ratios, as well as Falk Pollehne, Lars Rahm, and the crews of the research vessels r/v Maria S. Merian and r/v Professor Albrecht Penck for their support during the sampling. The authors acknowledge the funding from the BONUS+ EraNet Project AMBER.

Edited by: K. Suzuki

\section{References}

Algesten, G., Brydsten, L., Jonsson, P., Kortelainen, P., Lofgren, S., Rahm, L., Raike, A., Sobek, S., Tranvik, L., Wikner, J., and Jansson, M.: Organic carbon budget for the Gulf of Bothnia, J. Mar. Syst., 63, 155-161, doi:10.1016/j.jmarsys.2006.06.004, 2006.

Alling, V., Humborg, C., Morth, C. M., Rahm, L., and Pollehne, F.: Tracing terrestrial organic matter by delta S-34 and delta C-13 signatures in a subarctic estuary, Limnol. Oceanogr., 53, 2594 2602, 2008.

Alling, V., Sanchez-Garcia, L., Porcelli, D., Pugach, S., Vonk, J. E., van Dongen, B., Morth, C. M., Anderson, L. G., Sokolov, A., Andersson, P., Humborg, C., Semiletov, I., and Gustafsson, O.: Nonconservative behavior of dissolved organic carbon across the Laptev and East Siberian seas, Glob. Biogeochem. Cy., 24, 15, Gb4033, doi:10.1029/2010gb003834, 2010.

Amon, R. M. W. and Benner, R.: Rapid cycling og high-molecularweight dissolved organic matter in the ocean, Nature, 369, 549552, 1994.

Amon, R. M. W. and Benner, R.: Bacterial utilization of different size classes of dissolved organic matter, Limnol. Oceanogr., 41, 41-51, 1996. 
Benner, R., Biddanda, B., Black, B. and McCarthy, M.: Abundance, size distribution, and stable carbon and nitrogen isotopic compositions of marine organic matter isolated by tangential-flow ultrafiltration, Mar. Chem., 57, 243-263, doi:10.1016/s03044203(97)00013-3, 1997.

Benner, R.: Chemical Composition and Reactivity, in: Biogeochemistry of Marine Dissolved Organic Matter, edited by: Hansell, D. A. and Carlson, C. A., Academic Press, San Diego, 59-90, 2002.

Berg, G. M., Repeta, D. J., and LaRoche, J.: The role of the picoeukaryote Aureococcus anophagefferens in cycling of marine high-molecular weight dissolved organic nitrogen, Limnol. Oceanogr., 48, 1825-1830, 2003.

Bergström, S., Alexandersson, H., Carlsson, B., Josefsson, W., Karlsson, K.-G., and Westring, G.: Climate and Hydrology of the Baltic Basin., in: A Systems Analysis of the Baltic Sea, edited by: Wulff, F., Rahm, L., and Larsson, P., Ecological Studies, Springer, Berlin, 75-112, 2001.

Burgman, J. O., Calles, B., and Westman, F.: Conclusions from a ten year study of Oxygen-18 in precipitation and runoff in Sweden, Proceedings of an International Symposium on the use of isotope techniques in Water Resources Development, Vienna, 579-590, 1987.

Cauwet, G.: DOM in the coastal zone, in: Marine Dissolved Organic Matter, edited by: Hansell, D. A. and Carlson, C. A., Academic Press, San Diego, 579-609, 2002.

Craig, H. and Gordon, L. I.: Deuterium and oxygen 18 variations in the ocean and the marine atmosphere, in: Stable Isotopes in Oceanographic Studies and Paleotemperatures, edited by: Tongiorgi, E., Cons. Naz. Ric., Lab. Geol. Nucl., Pisa, 9-72, 1965.

Druffel, E. R. M., Bauer, J. E., Williams, P. M., Griffin, S., and Wolgast, D. M.: Seasonal variability of particulate organic radiocarbon in the northeast Pacific Ocean, J. Geophys. Res., 101, 20543-20552, doi:10.1029/96JC01850, 1996.

Friedlingstein, P., Cox, P., Betts, R., Bopp, L., Von Bloh, W., Brovkin, V., Cadule, P., Doney, S., Eby, M., Fung, I., Bala, G., John, J., Jones, C., Joos, F., Kato, T., Kawamiya, M., Knorr, W., Lindsay, K., Matthews, H. D., Raddatz, T., Rayner, P., Reick, C., Roeckner, E., Schnitzler, K. G., Schnur, R., Strassmann, K., Weaver, A. J., Yoshikawa, C., and Zeng, N.: Climate-carbon cycle feedback analysis: Results from the (CMIP)-M-4 model intercomparison, J. Climate, 19, 3337-3353, 2006.

Fry, B.: Conservative mixing of stable isotopes across estuarine salinity gradients: A conceptual framework for monitoring watershed influences on downstream fisheries production, Estuaries, 25, 264-271, 2002.

Fröhlich, K., Grabczak, J., and Rozanski, K.: Deuterium and Oxygen-18 in the Baltic Sea, Chem. Geol., 72, 77-83, 1988.

Guo, L. D., Tanaka, N., Schell, D. M., and Santschi, P. H.: Nitrogen and carbon isotopic composition of high-molecular-weight dissolved organic matter in marine environments, Mar. Ecol.-Prog. Ser., 252, 51-60, 2003.

Guo, L. D., White, D. M., Xu, C., and Santschi, P. H.: Chemical and isotopic composition of high-molecular-weight dissolved organic matter from the Mississippi River plume, Mar. Chem., 114, 63-71, doi:10.1016/j.marchem.2009.04.002, 2009.

Helcom: Seminar on review of progress made in water protection measures, Baltic Sea Environment Proceedings, 14, 436 pp., 1983.
Helcom: The Fourth Baltic Sea Pollution Load Compilation (PLC4), Helsinki Comission, BSEP93, 188 pp., 2004.

Humborg, C., Morth, C. M., Sundbom, M., Borg, H., Blenckner, T., Giesler, R., and Ittekkot, V.: $\mathrm{CO}(2)$ supersaturation along the aquatic conduit in Swedish watersheds as constrained by terrestrial respiration, aquatic respiration and weathering, Global Change Biol., 16, 1966-1978, doi:10.1111/j.13652486.2009.02092.x, 2010.

IPCC: Climate Change 2001: The Scientific Basis - Contribution of Working Group I to the Third Assessment Report of the Intergovernmental Panel on Climate Change, New York, 881 pp., 2001.

Kaldy, J. E., Cifuentes, L. A., and Brock, D.: Using stable isotope analyses to assess carbon dynamics in a shallow subtropical estuary, Estuaries, 28, 86-95, doi:10.1007/bf02732756, 2005.

Korth, F., Deutsch, B., Liskow, I., and Voss, M.: Uptake of dissolved organic nitrogen by heterotrophic bacteria and phytoplankton along a salinity gradient from the North Sea to the Baltic Sea, Biogeochemistry, Springer Netherlands, ISSN 1573515X, doi:10.1007/s10533-011-9656-1, September 2011.

Kuliński, K. and Pempkowiak, J.: The carbon budget of the Baltic Sea, Biogeosciences, 8, 3219-3230, doi:10.5194/bg-83219-2011, 2011.

Larsson, J., Gustafsson, O., and Ingri, J.: Evaluation and optimization of two complementary cross-flow ultrafiltration systems toward isolation of coastal surface water colloids, Environ. Sci. Technol., 36, 2236-2241, doi:10.1021/es010325v, 2002.

Lass, H. U., Mohrholz, V., and Seifert, T.: On pathways and residence time of saltwater plumes in the Arkona Sea, J. Geophys. Res.-Oceans, 110, 24, C11019, doi:10.1029/2004jc002848, 2005.

Letscher, R. T., Hansell, D. A., and Kadko, D.: Rapid removal of terrigenous dissolved organic carbon over the Eurasian shelves of the Arctic Ocean, Mar. Chem., 123, 78-87, doi:10.1016/j.marchem.2010.10.002, 2011.

Macko, S. A. and Estep, M. L. F.: Microbial alteration of stable nitrogen and carbon isotopic compositions of organic matter, Org. Geochem., 6, 787-790, 1984.

McCallister, S. L., Bauer, J. E., Ducklow, H. W., and Canuel, E. A.: Sources of estuarine dissolved and particulate organic matter: A multi-tracer approach, Org. Geochem., 37, 454-468, doi:10.1016/j.orggeochem.2005.12.005, 2006.

Meybeck, M.: How to establish and use world budgets of riverine material, in: Physical and chemical weathering in geochemical cycles, edited by: Lerman, A. and Meybeck, M., Kluwer Academic, Dordrecht, 247-272, 1988.

Moran, M. A. and Zepp, R. G.: Role of photoreactions in the formation of biologically labile compounds from dissolved organic matter, Limnol. Oceanogr., 42, 1307-1316, 1997.

Nausch, G., Feistel, R., Umlauf, L., Nagel, K., and Siegel, H.: Hydrographisch-chemische Zustandseinschätzung der Ostsee, Leibniz- Institut für Ostseeforschung Warnemünde, Warnemuende, 2010.

Neumann, G. H., Fonselius, S., and Wahlman, L.: Measurements on the content of non-volatile organic material in atmospheric precipitation, Int. J. Air Poll., 2, 132-141, 1959.

Norrman, B., Zweifel, U. L., Hopkinson, C. S., and Fry, B.: Production and utilization of dissolved organic carbon during an experimental diatom bloom, Limnol. Oceanogr., 40, 898-907, 1995. 
Otero, E., Culp, R., Noakes, J. E., and Hodson, R. E.: The distribution and delta $\mathrm{C}-13$ of dissolved organic carbon and its humic fraction in estuaries of southeastern USA, Estuar. Coast. Shelf Sci., 56, 1187-1194, doi:10.1016/s0272-7714(02)00330-x, 2003.

Peterson, B. J. and Fry, B.: Stable isotopes in ecosystem studies, Annual Review of Ecology and Systematics, 18, 293-320, doi:10.1146/annurev.ecolsys.18.1.293, 1987.

Pitkänen, H., Lehtoranta, J., and Peltonen, H.: The Gulf of Finland, in: Ecology of Baltic Coastal Waters, edited by: Schiewer, U., Ecological Studies, Springer, Heidelberg, 2008.

Raymond, P. A. and Bauer, J. E.: Use of ${ }^{14} \mathrm{C}$ and ${ }^{13} \mathrm{C}$ natural abundances for evaluating riverine, estuarine, and coastal DOC and POC sources and cycling: a review and synthesis, Org. Geochem., 32, 469-485, 2001.

Rivkin, R.B., and Putt, M.: Heterotrophy and photoheterotrophy by Antarctic microalgae: Light-dependent incorporation of amino acids and glucose, J. Phycol., 23, 442-452, 1987.

Rochelle-Newall, E., Pizay, M.-D., Middelburg, J. J., Boschker, H. T. S., and Gattuso, J.-P.: Degradation of riverine dissolved organic matter by seawater bacteria, Aquat. Microb. Ecol., 37, 922, 2004.

Rolff, C. and Elmgren, R.: Use of riverine organic matter in plankton food webs of the Baltic Sea, Mar. Ecol.-Prog. Ser., 197, 81101, doi:10.3354/meps197081, 2000.

Rosenstock, B., Zwisler, W., and Simon, M.: Bacterial consumption of humic and non-humic low and high molecular weight DOM and the effect of solar irradiation on the turnover of labile DOM in the southern ocean, Microb. Ecol., 50, 90-101, doi:10.1007/s00248-004-0116-5, 2005.

Savchuk, O. P.: Resolving the Baltic Sea into seven subbasins: $\mathrm{N}$ and $\mathrm{P}$ budgets for 1991-1999, J. Mar. Syst., 56, 1-15, doi:10.1016/j.jmarsys.2004.08.005, 2005.

Schmidt, G. A., Bigg, G. R., and Rohling, E. J.: Global Seawater Oxygen-18 Database - v1.21, available at: http://data.giss.nasa. gov/o18data/, last access: 30 November 2011, 1999.

Schuur, E. A. G., Bockheim, J., Canadell, J. G., Euskirchen, E., Field, C. B., Goryachkin, S. V., Hagemann, S., Kuhry, P., Lafleur, P. M., Lee, H., Mazhitova, G., Nelson, F. E., Rinke, A., Romanovsky, V. E., Shiklomanov, N., Tarnocai, C., Venevsky, S., Vogel, J. G., and Zimov, S. A.: Vulnerability of permafrost carbon to climate change: Implications for the global carbon cycle, Bioscience, 58, 701-714, doi:10.1641/b580807, 2008.

Seitzinger, S. P. and Sanders, R. W.: Contribution of dissolved organic nitrogen from rivers to estuarine eutrophication, Mar. Ecol.-Prog. Ser., 159, 1-12, 1997.

Sigleo, A. C. and Macko, S. A.: Carbon and nitrogen isotopes in suspended particles and colloids, Chesapeake and San Francisco estuaries, USA, Estuar. Coast. Shelf Sci., 54, 701-711, doi:10.1006/ecss.2001.0853, 2002.
Stepanauskas, R., Leonardson, L., and Tranvik, L. J.: Bioavailability of wetland-derived DON to freshwater and marine bacterioplankton, Limnol. Oceanogr., 44, 1477-1485, 1999.

Stepanauskas, R., Jorgensen, N. O. G., Eigaard, O. R., Zvikas, A., Tranvik, L. J., and Leonardson, L.: Summer inputs of riverine nutrients to the Baltic Sea: Bioavailability and eutrophication relevance, Ecol. Monogr., 72, 579-597, 2002.

Stepanauskas, R., Moran, M. A., Bergamasch, B. A., and Hollibaugh, J. T.: Sources, bioavailabitity, and photoreactivity of dissolved organic carbon in the Sacramento-San Joaquin River Delta, Biogeochemistry, 74, 131-149, doi:10.1007/s10533-0043361-2, 2005.

Sulzberger, B., and Durisch-Kaiser, E.: Chemical characterization of dissolved organic matter (DOM): A prerequisite for understanding UV-induced changes of DOM absorption properties and bioavailability, Aquat. Sci., 71, 104-126, doi:10.1007/s00027008-8082-5, 2009.

Tarnocai, C., Canadell, J. G., Schuur, E. A. G., Kuhry, P., Mazhitova, G., and Zimov, S.: Soil organic carbon pools in the northern circumpolar permafrost region, Glob. Biogeochem. Cy., 23, Gb2023, doi:10.1029/2008gb003327, 2009.

Van den Meersche, K., Van Rijswijk, P., Soetaert, K., and Middelburg, J. J.: Autochthonous and allochthonous contributions to mesozooplankton diet in a tidal river and estuary: Integrating carbon isotope and fatty acid constraints, Limnol. Oceanogr., 54, 62-74, doi:10.4319/1o.2009.54.1.0062, 2009.

Wiegner, T. N. and Seitzinger, S. P.: Seasonal bioavailability of dissolved organic carbon and nitrogen from pristine and polluted freshwater wetlands, Limnol. Oceanogr., 49, 1703-1712, 2004.

Wiegner, T. N., Seitzinger, S. P., Glibert, P. M., and Bronk, D. A.: Bioavailability of dissolved organic nitrogen and carbon from nine rivers in the eastern United States, Aquat. Microb. Ecol., 43, 277-287, 2006.

Williams, C. J., Yamashita, Y., Wilson, H. F., Jaffe, R., and Xenopoulos, M. A.: Unraveling the role of land use and microbial activity in shaping dissolved organic matter characteristics in stream ecosystems, Limnol. Oceanogr., 55, 1159-1171, doi:10.4319/lo.2010.55.3.1159, 2010.

Voss, M., Dippner, J. W., Humborg, C., Hurdler, J., Korth, F., Neumann, T., Schernewski, G., and Venohr, M.: History and scenarios of future development of Baltic Sea eutrophication, Estuar. Coast. Shelf Sci., 92, 307-322, doi:10.1016/j.ecss.2010.12.037, 2011.

Zimov, S. A., Schuur, E. A. G., and Chapin, F. S.: Permafrost and the global carbon budget, Science, 312, 1612-1613, doi:10.1126/science.1128908, 2006.

Zimov, N. S., Zimov, S. A., Zimova, A. E., Zimova, G. M., Chuprynin, V. I., and Chapin, F. S.: Carbon storage in permafrost and soils of the mammoth tundra-steppe biome: Role in the global carbon budget, Geophys. Res. Lett., 36, L02502, doi:10.1029/2008g1036332, 2009. 